Trump and Charisma

\title{
Countering Trump: Toward a Theory of Charismatic Counter-Roles
}

\author{
Paul Joosse, University of Hong Kong
}

$\mathrm{T}$ his article conducts a negative reading of Weber's ideal type of charismatic authority, seeking to anticipate and discern hidden social interactants that are implicated in his descriptions of charismatic social processes. In so doing, this article advances the "charismatic counter-role" as an umbrella term that captures the performative bearing of a variety of actors on processes of charismatic interaction. Specifically, in addition to devoted followers (already much discussed in the literature), this typology contains unworthy challengers (competitors who fall short when judged by the new terms of legitimacy that the charismatic leader creatively establishes); and colossal players (interlocutors that are appropriately "to scale" for highlighting the extraordinary missions to which the charismatic leader aspires). Together, these charismatic counter-roles interact in ways that comprise a charismatic social system that gives a better account than has heretofore been available for the unstoppable momentum of charismatic challenges. Using the "Trump phenomenon" of 2015-2016 as its empirical source, and employing analytical tools from symbolic interactionist and performative approaches to social theory, this article has implications for future studies of how charisma destabilizes traditional and/or rational-legal social orders.

\section{Introduction}

Bourdieu once noted that it was possible to read "between the lines" of Max Weber's writings on charisma and find descriptions of relations between actors "that may be termed interactionist (in the sense in which we speak today of symbolic interactionism)" ([1971] 1987, 121, emphasis in the original). Indeed, despite recurrent suspicion about the concept's Carlylian overtones (Gerth and Mills [1946] 1958, 53; Friedland 1964, 20, Joosse 2014; Lindholm 1990), and in addition to important psychodynamic treatments (Dawson 2006; Kohut

Direct correspondence to Paul Joosse, PhD, Assistant Professor, Department of Sociology, University of Hong Kong, Hong Kong; telephone: +852 6464 3090; e-mail: pjoosse@hku.hk. I would like to thank Arne L. Kalleberg and anonymous reviewers at Social Forces for helpful comments. Thanks are also due to Gary Hamilton, Randall Collins, Peter Baehr, Graeme Lang, Kevin D. Haggerty, Joshua Derman, Julian Groves, Xiaoli Tian, Liping Wang, and Robin Wiley for comments and conversations about earlier drafts of this article. This paper was presented at the ASA's Theory Section session, "New Developments in Classical Theory", August, 2017. 
1976; Oakes 1997; Schiffer 1973), a substantial literature has arisen that bears out the notion that interactionism offers explanatory power with respect to charisma's production, reception, and routinization (Blasi 1991; Couch 1989; DuPertius 1986; Finlay 2002; Joosse 2017a, 2017b; Reed 2013; Smith 2013; Wallis 1982; Wasielewski 1985).

Within this tradition there have been two approaches that can be seen as distinct yet complementary. The first stresses the dramaturgical aspects of charismatic performance, working from the notion that the charismatic individual "is not only a person but a personage, a public character in a public drama" (Blasi 1991, 4-5; see also Dawson 2006, 19-20; Gardner and Avolio 1998; Joosse 2012; Reed 2013). While Weber tended to focus reductively on the leader's provision of oftentimes miraculous "proofs" to followers ([1922] 1978, 242-44, $266,441)$, this more recent scholarship has drawn on theoretical insights from the performative turn in cultural sociology in a way that gives flesh to Weber's rather skeletal account of charismatic affect (Goffman 1959; Searle 1969; Butler 1990; for a full discussion see Reed [2013, 261-67]). Another profit derived from this approach has been a more robust account of the "life-cycle" of charismatic ruptures. While Weber stressed that charisma is turbulent and unstable, something that exists only "in statu nascendi" [in the process of formation] ([1922] 1978, 246, also 1120; Jameson 1973), Isaac Reed's performative analysis of Bacon's rebellion has shown how charismatic turbulence can be mediated by "iterative, self-referential spiral[s] of success" that grow into sustained challenges to the social order $(2013,255)$. This approach accounts for the extended temporal scope evident in many charismatic upheavals, counterbalancing Weber's preoccupation with charisma's end ([1922] 1978, 1121-48).

The second interactionist approach has sought to look beyond leaders per se in an effort to describe the "follower-side" of charisma (Finlay 2002; Joosse 2017a; Junker 2014; Zhe 2008, 51-56). As Bryan Wilson wryly noted:

If a man runs naked down the street proclaiming that he alone can save others from impending doom, and if he immediately wins a following, then he is a charismatic leader... If he does not win a following, he is simply a lunatic. $(1975,7)$

Thus, while Weber relegated charismatic followers to the "negative space" of passive voice in his oft-quoted definition of charisma (Joosse 2014, 276; Weber [1922] 1978, 241), ${ }^{1}$ recent work has sought to describe the social field populated by followers who do the crucial work of attributing charisma. Some writers have explored how followers or disciples exercise their agency in an "outward" direction, shaping the public image of the leader and setting political agendas within charismatic social movements (Chan 2013; Junker 2014). Others have focused on the "inward" comportment of disciples whose displays of loyalty and devotion are confidence-building preconditions for the leader's adoption of a charismatic identity (Couch 1989; Joosse 2017a; Wallis 1982). More recently, Abrutyn and Van Ness have described how charismatic institutional entrepreneurs are "responsible for creating generalized roles with basic membership criteria and relatively generalized expectations and obligations like 
'consumer,' 'patient,' and 'fan'” $(2015,59)$. These "counter-roles...recognize elites' legitimate claims and...exchange intangible resources like commitment and loyalty, as well as more tangible resources like material wealth, with elites" (Abrutyn 2009. 458; also Wallis [1982]; Downton [1973], for similar "transactionalist" accounts).

All of this work sheds valuable light on relationships that are endogenous to charismatic groups; that is, those interactions between leaders and followers that constitute the "charismatic bond." We know, however, that charismatic affect is not always produced in such a cooperative manner; nor does it manifest solely within the closed interactional sphere delineated by leader-follower relationships. As Weber stressed, charisma strikes the onlooker by virtue of being "sharply opposed" to bureaucratic and traditional social structures that are already in place $(1968,51,29,39$; [1922] 1978, 212-301), and charismatic personae are defined in contradistinction to the leaders who head up such structures ([1922] 1978, 244).

Charismatic affect also cannot be completely captured with reference to the tidy oppositions Weber sets up between charisma and the "bureaucratic" or "traditional." All of Weber's myriad charismatics-from the "epileptoid" to the "berserker warrior" to the "religious saint" to the "party leader"-are distinguished by a more basic unifying criterion, namely their status of being "set apart" [Außertäglichen] or "specifically outside the everyday" (Weber [1922] 1978, 241, 1111, 1115; see also Shils 1965. 199). As the most protean and "natural" form of social power (Weber [1922] 1978, 1111) — the prime mover of institutional creation and destruction (Abrutyn and Van Ness 2015, 56; Eisenstadt 1968)—there is thus an open quality to this "uncommonness" that hints at a rich array of characters who may contrast with the charismatic leader. Willner and Willner $(1965,81)$ suggested the possibility of exploring such variability, observing that the social production of extraordinary individuals involves "several groups...and several stages of validation." What we need, therefore, is to index the various modes of distinction that enable charismatic leaders to emerge, in relief, against an interactional backdrop populated by various non-charismatic others.

Here, Abrutyn and Van Ness's (2015) notion of charismatic "counter-roles" is particularly apt, but in a way that calls for extensions beyond their formulation about 'fans' 'patients' and 'consumers.'" In the social movement literature, the influence, role, and function of "non-believing" interactants have been explored extensively. Indeed, oppositional, dialectical, and countervailing dynamics involving elites, enemies, and bystanders have been a mainstay of theoretical elaboration (Benford and Snow 2000, 625-27; della Porta 1995; Gamson 1992; Tarrow 1998; Zald and Unseem 1987). The charisma literature would do well to follow this lead.

Perhaps the closest forerunner to the approach advocated in this paper has been Orrin Klapp, a prolific taxonomist of social types who documented processes through which "symbolic leaders" ([1964] 2009) emerge and come to inhabit their roles. Klapp's work has received scant attention in the charisma literature (cf. Wasielewski 1985, 219, n. 1), even though his macro-cultural vision-in which 
"heroes, villains, and fools" (1962) contrast and illuminate one another-is apt for describing charisma's performative dimensions (as Klapp himself briefly noted [1948, 135]).

This article therefore combines such dramaturgical and interactionist approaches with Weber's ideal-typical vision to develop an expanded typology of charismatic counter-roles. It does this by looking beyond "followership" to examine how rivals and other interlocutors contribute to charismatic performance. In addition to devoted followers, then, this article predicts the presence of two new counter-roles. First, since Weber described charismatic leaders as being driven toward establishing new forms of legitimacy, we can anticipate that unworthy challengers - rivals who publicly fail amid the newly established/charismatic criteria-will emerge as foils to the charismatic leader. These characters are analogous to the "fools" described by Klapp $(1949,1962)$. Second, because of the audacious nature of charismatic missions as Weber describes them, we can similarly expect that colossal players-people and institutions that are "to scale" with the leader's ambitions-will emerge to fill a key role in the leader's bid for status elevation. These "players" correspond, in turn, with Klapp's (1962) "villains." Because devoted followers, unworthy challengers, and colossal players each bring forth a different type of role-contrast that actualizes charismatic legitimacy, the typology coheres according to an integrative logic that is predicated on complementary valences of charismatic distinction. In short, these counter-roles "work together" in a manner that gives a better account than has heretofore been available of the mise-en-scène of charismatic upheaval.

\section{Case and Method}

Even though contemporary academic literature on charisma tends to be dominated by studies of fringe social phenomena like new religious movements, megachurches, and terrorism (e.g., Junker 2014; Hofmann 2016; Wignall 2016), there is no reason why the category should not also be relevant for interpreting political processes at what Geertz (1977) referred to as the cultural "centers" of society (also Weber [1919] 1946, 79, 296; Eisenstadt 1968; Shils 1965). Indeed, the original impetus for Weber's development of "charisma" was his concern with the "Caesarism" that hovered over German politics from Bismarck onward (Baehr 2008, 59-114). Moreover, the uptake and eventual canonization of Weber by the English-speaking world was in no small measure resultant of the concept's utility for early analyses of the "Hitler movement" (Abel 1937; Gerth 1940; for a full account, see Derman [2012]).

This article reinvigorates this tradition by illustrating the aforementioned typology with reference to mainstream politics. In particular, the 2015-2016 Republican Party primary contests are examined as a setting that was propitious for Donald Trump's charismatic rise. Without actually using the word, several commentators spoke about Trump during this time in ways that are unmistakably resonant with Weber's ideal type. For example, talk-radio host Rush Limbaugh noted early in 2016 that: 
Everything he's doing goes against the book.... Everything that any analyst or consultant or professional would tell you not to do, Donald Trump is doing it, and he's leading the pack [of GOP candidates]. This creates its own set of emotions and feelings and thoughts that run from person to person.... Trump is functioning totally outside this structure that has existed for decades. As such, the people who are only familiar with the structure and believe in it and cherish it and want to protect it, feel threatened in ways that you can't even comprehend. (emphasis added)

For the most part, we are still waiting for academic treatments to emerge. Social movements scholar David Meyer (2016) has been an early voice, maintaining that Trump's campaign was charismatic because it was "based on the promise of exceptional personal characteristics and action." Wagner-Pacifici and Tavory (2017) recently described Trump's appeal in terms of a distinct yearning on the part of the electorate for a "charismatic rupture" within routine politics. Thus far, however, Arlie Hochschild's ethnography of the Tea Party is proving to be the best source for rich descriptions of the charismatic tenor of Trump's affect and reception. To wit:

The day before the Louisiana Republican primary in March 2016, I watched Donald Trump's Boeing 757 descend from the sky at the Lakefront Airport in New Orleans. Inside the crowded hangar, Elton John's "Rocket Man" was playing. Red, white, and blue strobe lights roved sideways and up. Cell phones snapped photos of the blond-haired candidate as he stood before thousands waving and shaking signs that read MAKE AMERICA GREAT AGAIN. A small, wiry man bearing this sign with both hands, eyes afire, called out within earshot, "To be in the presence of such a man! To be in the presence of such a man." There seemed to be in this man's call...a note of reverence, even ecstasy. $(2016,683)$

Presidential elections are classic examples of what Althusser (1967) referred to as overdetermination, in which myriad factors bear causal significance for societal-political outcomes. For the most part, the present article holds in abeyance questions pertaining to the macro-historical/structural factors that have enabled Trump's rise. While analyses of such factors are no doubt important (and no doubt in the offing), here, justification is given for centralizing the performative dimensions of Trump's candidacy as a means of gaining insight into the "Trump phenomenon."

This strategy is fitting not least because Trump himself came into the race in 2015 as an already-seasoned performer, steeped in the praxis of celebrity culture, from his earliest days as a business impresario whose life was fodder for the tabloid press, to stints in professional wrestling and as an owner/promoter for Miss Universe pageants, to his appearances as an actor in 13 films and many more television programs, and finally, until 2015, as a producer and reality-TV star on The Apprentice-a show that revolved around the construction of his 
business acumen and extraordinary "boss" status. It was not merely poetic flourish, then, when Meryl Streep compared Trump's presidential run to the performances of film stars who had been nominated at the 2017 Golden Globe awards:

There were many, many, many powerful performances this year... breathtaking, compassionate work.

But there was one performance this year that stunned me... Not because it was good; there was nothing good about it. But it was effective and it did its job. It made its intended audience laugh, and show their teeth.... I still can't get it out of my head, because it wasn't in a movie. It was real life.

Jeffrey Green recently advocated for an "ocular" approach to the study of charisma in modern politics that responds to the "unpleasant but acute reality that mass democracies today are defined by spectatorship" $(2010,104)$. Anyone who watched the events of the past year will recognize that Trump's candidacy exemplified this principle almost to the point of caricature; something that underscores the notion that the dramaturgical dimensions of "the Trump phenomenon" demand investigation in their own right.

News coverage was largely insufficient for capturing Trump's interaction with counter-roles, since these sources tended to remove Trump's statements from their original interactional setting, reproducing them as stand-alone datums within a new editorial context. For this reason, the following analysis draws on the 12 GOP debates that occurred during the course of Trump's 2015-2016 GOP nomination bid, 20 speeches made by Trump at rallies during the primaries, and several interviews that Trump conducted between the announcement of his presidential run (June 16, 2015) and the final primaries (June 7, 2016), by which point his status as the presumptive GOP nominee was mathematically secured. The debate transcripts were collated into a document (571 pages, or 276,711 words). The analysis is based on full transcriptions of the debates and rally speeches, and the collection of material from Trump's media interviews was selected with the aim of finding sources that were unedited within the clips themselves.

Because the analytical tack involved working backward from Weber's ideal type, reading "between the lines" in the manner described by Bourdieu ([1971] $1987,121)$, code generation was deductive to a larger measure than is usually the case with papers that operate with a (putatively) more purely inductive epistemology (usually under the aegis of some form of grounded theory). Instead, the current research model combines evidentiary (inductive) and social-theoretical (deductive) modes of reasoning reiteratively, and is thus consistent with what Charles Ragin (1994) has called "retroduction." Such an approach is especially useful when conducting case studies that are already pre-tasked toward some larger theoretical question or set of questions; what Timmermans and Tavory $(2012,167)$ describe as “an ongoing pragmatic process of 'puzzling out' and 
problem-solving that draws on existing ways of understanding what the phenomenon "is a case of."”

Because of this process of "double-fitting" between data and theory, each of the three following subsections first describes the reasoning, from the theory, for why we might generate a predictive hypothesis about the presence of a particular counter-role in the charismatic milieu. This is then followed by evidence, from the case, for the empirical reality of the counter-role as a charisma-enhancing feature of Donald Trump's political performances. My research assistant and I initially printed off the same selected 15 percent of the material and hand-coded it independently with the aim of generating themes that were derived from and applicable to the literature on charismatic leadership. We then compared efforts to discuss rationales for the coding practices. These discussions were used to develop a general thematic scheme that captured various points of consensus. Ultimately, these themes, and subsequent refinements within them, were used to approach the remaining 85 percent of the data, selections of which appear below.

\section{The Charismatic Counter-Roles}

\section{Devoted Followers}

The first recognizable counter-role to charismatic performance-already thoroughly discussed in the literature-is that of the devoted follower. Contrary to popular conceptions, Weber places followers, not leaders, at the center of his etiological account of charismatic power, since "it is recognition on the part of those subject to authority which is decisive for the validity of charisma" ([1922] 1978, 242). The history of charismatic enthusiasm shows that certain followers may become famous in their own right as they gain recognition as exemplary devotees that others should model (as did Akrura, the great disciple of Krishna, for example). More typically, however, they resemble the Myrmidons-faceless, nameless supporters who are subsumed into crowds, audiences, or (as the case may be today) aggregated together in polls, rallies, or blocs of Twitter followers.

The implications of role-acceptance for charismatic followers are radically different from those that attend low-status positions in more conventional hierarchies. Whereas the rank and file within traditional and bureaucratic structures may be indifferent to their roles and tasks, getting by in the manner of "going through the motions" (Goffman 1961, 83-152), charismatic interaction "revolutionizes men from within," such that the charismatic laity is strikingly enthusiastic and affectively sincere (Weber [1922] 1978, 1116, 243). As Bendix stressed, in charismatic interaction there is "a degree of commitment on the part of disciples that has no parallel in the other types of domination" $(1960,300)$. Moreover, whereas adherence to non-charismatic structures involves a fealty to regulation or custom, charismatic attraction is much more narrowly concentrated as an emotional attachment to a single indispensable personality (Weber [1922] 1978, 1113; Wasielewski 1985). 
When appreciated dramaturgically, devoted followership can be conceived as a "counter-role" because it creates and highlights differentials in status and power between the leader and the led. By coming to the leader, followers affirm the value of the leader and his or her message. By supplicating themselves, they create the differential in status that constitutes the leader's exaltation. By willingly occupying the receiving end of unidirectional communication, they affirm the rightness of the social practice in which the leader is heard above all others. These are features of what Collins (2004) referred to as the power to command deference, or "D-Power." This discrepancy of recognition-in which one person is widely known, and the many others present are not-can also be seen as the most basic precondition for charismatic acclamation, and it is in this performative sense that the charismatic leader comes to be seen as possessing "an extraordinary quality which is not accessible to everyone and which typically overshadows the charismatic subjects" (Weber [1922] 1978, 1135, emphasis added).

During the campaign, Donald Trump seems to have had a keen intuition about the importance of highlighting his own extraordinary status by pointing to the performances of legions of devoted followers. He was fond, for example, of discussing the numbers of people that attend his rallies. The crowds have indeed been impressive (e.g., Schleifer and Gray 2015), but the attendance numbers he reports were also frequently contested by opponents and reporters during the campaign (Adams 2015; Campbell 2015). In response, Trump has at times undertaken to literally bring devotional performances into fuller view. At rallies in Iowa, Nevada, Texas, and Mississippi, for example, he repeatedly berated camera operators, demanding that they "turn the camera around" to show the crowd. Trump's concern with representation was particularly evident at a January 2, 2016, rally in Biloxi, Mississippi:

I tell you, I go home all the time and my wife, she watches on television...and she always says..."darling, did you have many people there?" I say "What?" She said, "they never take the camera off your face." They [the press] don't want to show the crowd.... They're really dishonest people. No, they are. [building applause].... I thought they couldn't turn [the cameras]. I thought mechanically they didn't turn. They turn. [cheering] They turn. Put a guy over in the corner that's protesting, and you'll see those cameras, they'll be in 14 different positions [laughter]. It's so damn unfair, the press [building cheers]. It's terrible [repeat].... Look at the people up there, every corner [gesturing up into the stands], and then outside of the arena.... It would actually be good television, but they wanna marginalize all of us [loud cheering].

Polls were also central to Trump's efforts in this regard. While favorable polls provide an occasion for self-congratulation for any candidate who is doing well, as Nick Gass (2015) of Politico remarked, "poll numbers are, unlike perhaps any candidate in history, central to Trump's pitch to voters." Trump's speeches, debates, and interviews were replete with this "pitch" in which comments about polls were used to service the notion that "people love me...everybody loves 
me" (quoted in Cooper 2015). Most famously, at a January 2016 campaign rally in Iowa, Trump remarked:

You know what else they say about my people-the polls?-they say I have the most loyal people. Did you see that? I could stand in the middle of Fifth Avenue and shoot somebody and I wouldn't lose any voters, OK? It's like incredible.... They say [referencing a poll that asks respondents] "Will you stay [voting for Trump]?" [The category] "Absolutely"-I think it's 68 or 69 percent. [On the question of], "Will you most likely stay?” That gets into the 90 s. Other guys are like at 10 !

Early in his run, Trump frequently carried out an oath ritual with attendees of his rallies in which they would raise their hands and promise to vote for him. While this practice earned comparisons with the Hitlergruß (Velencia 2016), it should also remind us of Weber's insistence that charisma "creates, or demands new obligations," and that for those who choose to be followers of a charismatic leader, "recognition is a duty" ([1922] 1978, 244).

The minimal effect of such displays of devotion is to direct non-devoted onlookers toward the leader as a focal point for their own attention. This "pointer" function is a precondition for a potentially much deeper engagement, however. In his study of mobilization in the Iranian revolution, for example, Kurzman found that perceived political opportunities are just as relevant as actual opportunities when it comes to individuals' proclivities for participation, since "individuals are more likely to participate in the protest movement when they expect large numbers of people to participate" $(1996,154)$. Thus, leaders may be tempted to draw attention to the performances of devoted followers as a means of setting up conditions that are favorable for motivating others to join the movement. While for rational actors this motivational mechanism can involve tipping the scale in terms of a "bandwagon" calculation (Oberschall 1994), charismatic attraction to a leader spreads through an additional vector, involving a mimetic multiplication of desire (Girard [1965] 2009). That is, the leader's value is constructed by means of a triangular relationship between the leader, enraptured followers, and witnesses who are party to, and potentially inspired by, the devotional performances of the followers (Joosse 2017a). Because the social value of the charismatic leader is created through mutual exchanges of valuation and recognition among followers, the counter-role of the devoted follower can be an effective performative element that favors the ascription of charismatic status to a leader. In short, as Trump shines light on the performances of devoted followers, his own persona acquires a charismatic sheen.

\section{Unworthy Challengers}

The "unworthy challenger" is another important character foil for the charismatic leader, but in a different sense from the devoted followers described above. Whereas followers impart legitimacy by means of a performed devotion, charismatic success versus rivals stems from the leader's creative redefinition of legitimacy itself (Weber [1922] 1978, 213). As Weber tells us, "charismatic 
domination transforms all values," and its bearers are indifferent and intransigent in the face of "formal and regulated [processes of] appointment or dismissal" ([1922] 1978, 246). Put simply, the charismatic leader is much more apt to redraw the rules of status competition than play by them.

This creative destruction of protocols for legitimate leadership has dramatic implications for conventional rivals to the charismatic leader. Specifically, as the successful charismatic leader effects a new performative terrain, he or she is cast as eminently competent while the conventional rivals are rendered seemingly inexperienced, ill equipped, and outmoded. This transformation no doubt feels like a cruel trick to those vying for power on conventional terms, since the very qualities that would have made them worthy of leadership in the past become, in the light of the new charismatic criteria, the signal of their unworthiness. That is, just as the charismatic leader impresses the onlooker by means of a positive expression of their new vision and mission, so the conventional contender performs the inadequacy of the status quo.

It is clear that the $2015 / 2016$ GOP contests were beset by a prevailing political climate that favored those who would question traditional notions of political legitimacy. While every one of the first 44 presidents of the United States came into office with some experience in government or military service, the value of such qualifications has been increasingly uncertain in this "year of the outsider." Central to frustrations has been the legislative stalemate that has plagued the Congress, giving politicians in general an air of ineffectuality (Binder 2014). As conservative writer Peter Wehner (2015) noted in an op-ed for the New York Times, "for many Republican voters, governing experience appears to be downright disqualifying." Trump's self-presentation as a peerless businessman and "deal-maker" thus stands alongside Ben Carson's accomplishments as a neurosurgeon and Carly Fiorina's experience as a corporate executive as markers of a form of "outsider legitimacy" that gained currency in this latest GOP contest.

What marked out Trump as a singular candidate, however, distinguishing him even from other self-styled "outsiders," was his performative style. Trump's appearances have been a clinic in defiance of the norms of decorum that have up to this point guided political behavior. His combination of racist, sexist, and xenophobic statements with a puerile masculinity affected a combative style that simultaneously outraged and enthralled audiences, while ensuring maximum press coverage. As a consequence, everyone from White House press secretary Josh Earnest, to National Review writer Heather Macdonald, to 2012 GOP nominee Mitt Romney, pointed to Trump's behavior and statements in the media as things that "disqualify" him from the office of president (Eilperin and Jaffe 2015; Tait 2016; MacDonald 2016). Ted Cruz's communications director similarly lamented that "we're not in a version of his reality TV show. We're running for President of the United States. His action and his behavior is conduct unbecoming of someone who is running for President" (CNN 2016).

The irony of these sentiments about "qualifications" is that Trump's appearances in the media have, by dint of their performative success, pushed forward mediarelated transformations that were already underway with respect to how a 
candidate's "qualifications for president" are popularly evaluated. Communications scholars have produced a large body of work examining the political implications of the increasing fusion between news and entertainment (Brants and Neijens 1998; Thussu 2008; Moy, Xenos, and Hess 2005), and the rise of new media (Bennet 2012; Kushin and Yamamoto 2010; Shirky 2011). This work has built up a consensus that the underlying values that drive news production are increasingly being shaped by considerations of entertainment value, and that those who seek political office need to perform often, and perform well (Alexander 2010).

Trump was-in a way that his rivals were not-a performer who exceled under these new criteria of judgment. In a heavily mediatized era in which electoral fatigue takes its toll on voters and candidates alike, Trump responded consistently to the unremitting pressure to "deliver content"-as outlandish and objectionable as it may have been-whether it be on call-in morning news programs, or through prolific social media activity, or by delivering easily-clipped sound bites during the GOP debates and speeches. This consistent delivery resulted in an estimated \$2B worth of publicity for his campaign prior to March 2016 - nearly twice the all-in budgets of Obama and Romney's 2012 presidential campaigns (Confessore and Yourish 2016), a publicity that was doubly impactful in the zero-sum competition with rivals for prominence in the daily news cycles. Thus, while Trump consistently failed to acquire legitimacy in a traditional manner, his ability to breech established modes of political discourse with impunity comes off as an "extraordinary quality" in the very sense that Weber indicated would be salient for charismatic affectation ([1922] 1978, 241, 1111, 1115).

The political establishment may have been slow to recognize the importance of Trump's advantages amid these media transformations, but they were not lost on those who are more familiar with the performative dynamics of "infotainment." In an interview with Face the Nation in late 2015, for example, talk show host Stephen Colbert commented that he has "respect for Trump for knowing who the real audience is" (Dickerson 2015). In an interview, comedian Louis CK explained why he felt the need to email a request to his fans, asking them to stop voting for Trump: "look, I think Trump is more from my world than he is from politics, you know? He's one of us. He's a showbiz guy. He's an entertainer, so I felt like we're responsible for him" (Rose 2016). Seth Grossman (2015), a filmmaker and reality television producer, wrote a guest column for the New York Times, remarking that "I've been working in reality television for 10 years, and I can tell you that Mr. Trump is exactly what we look for in our casting process. He's uncomplicated and authentic: You can understand his entire personality from a 15 -second sound bite."

Trump's talent for "zingers"-ripostes that elide and diffuse criticism in an entertaining manner-was evidenced by the raucous cheers that erupted after the following exchange with Marco Rubio: 
Rubio: You're the only person on the stage that's ever been fined for hiring people to work on your projects illegally. You hired some workers from Poland.

Trump [cutting in]: No, I'm the only one on this stage that's hired people. You haven't hired anybody [erupting laughter and applause]. (GOP debate, Houston, February 25, 2016)

Similarly, when Fox debate moderator Megyn Kelly confronted Trump about his history of referring to women as "fat pigs, dogs, slobs, and disgusting animals," his response-“'Only [to] Rosie O'Donnell"-achieved one of the loudest crowd responses during any of the debates. By invoking his previous talk-show battles with O'Donnell, Trump revealed the moment to be one that was cut whole-cloth from the new entertainment paradigm into which electoral culture had shifted. While Trump was acting in a manner that was performatively in continuance with his persona as a premier entertainer, enacted on the GOP debate stage, this made for a stark contrast with the more traditional norms of American electoral politics, to which his opponents continued to adhere.

Further in this vein, it should not go unnoticed that the characterizations that Trump gives to his opponents frequently reference their inability to meet the performative demands of the modern mediated electoral process-demands that he seemed to be able to meet so effortlessly. One consistent line of attack has been against his opponents' use of teleprompters, as displayed at a rally in August 2015 in Iowa:

These other guys, they go around [and] they make a speech in front of 21 people. Nobody cares. They... read the same speech. They have teleprompters. I say we should outlaw teleprompters for anybody-right? [loud cheering] For anybody, for anybody running for president [louder cheering]. You know how easy that would be? Instead of this [gesturing his current speech]_I'm working my ass off, OK?-Instead...I [could] just stand up [and say] "Ladies and gentlemen, thank you very much, it's wonderful to be in Iowa.".... No mistakes. No problems. But I walk in [and speak] live.... And by the way, they're getting phenomenal ratings...And you know, the old days, when I was with The Apprentice, they paid me a lot of money. They don't pay me anything [now]. You know, for the debate [on August 6, 2015], we had 24 million [viewers]. Now, normally there would be like two million people, right?... They had 24. I won't take credit for it but believe me, 100 percent it's me, 100 percent [loud cheering].

The debate on December 15 in Las Vegas was the occasion for a stark contrast between Trump and "establishment candidate" Jeb Bush. Throughout the debate, the performative contest between the two revolved around the (by now persistent) theme promulgated by Trump that Bush was someone who was "a very nice person" with "low energy." As if to confirm this characterization, during their exchanges Bush consistently struggled to get a word in, and Trump was able to talk over Bush and dominate the interactions ("I know you're trying 
to build up your energy, Jeb, but it's not working very well [audience laughter]"). By the end of the debate, with Bush clearly outmatched, Trump even began affecting a condescending faux-magnanimity toward his lesser rival:

I think it's very sad that CNN leads Jeb Bush, Governor Bush, down a road by starting off virtually all the questions [with] "Mr. Trump this, Mister" - I think it's very sad... And, frankly, I watched the first debate, and the first long number of questions were, "Mr. Trump said this, Mr. Trump said that. Mr. Trump"-these poor guys....

As Isaac Reed recently noted, "charismatic leaders are challengers; part of what makes them likely to succeed is the performative failure of their opponents" (2013, 281). The power of Trump's criticism of his opponents in these instances is that they invite the audience to partake in charismatic interactions as witnesses to such performative failure as "fools" (Klapp 1949). Capitalizing on the performative potential of novel and emergent forms of political legitimacy, Donald Trump has thus creatively worked to furnish his own public character with a supporting cast of charismatic counter-roles; namely, his unworthy challengers.

\section{Colossal Players}

"Colossal players" are for the most part hidden in the background of Weber's writings about charismatic authority. In a style indicative of someone bursting with too many examples, he names the Irish legend of Cuchulin and the "Homeric Achilles" as charismatic figures, for example, before hurrying on to a discussion about the "value-free" nature of his category ([1922] 1978, 1112). Readers not familiar with Celtic and Greek lore will be unaware, therefore, that both of these legends make dramatic use of colossal foes for the establishment of the charismatic stature of their heroes (Achilles's esteem derives most notably from his slaying of Hector, the greatest of the Trojan warriors, and Cuchulin, the "beardless youth" of Irish lore, is most famous for single-handedly defeating the army of Queen Medb [see Smith 2013, 44]). "Colossal players" are also central features of the Christian theology of grace that served as a conceptual substructure for much of Weber's thinking on charisma (Joosse 2014; Smith 1998). From the selection of Moses, a man "slow of speech and tongue," to face the Pharaoh in a bid to liberate the Israelites from enslavement; to Gideon's staggering defeat of the formidable Midianites with only 300 men; to the selection of David, the youngest of the sons of Jesse, to battle Goliath with no armor and a simple sling; all these display how elephantine opponents are performatively relevant to charismatic affect because preposterous "underdog" victories become a form of proof of blessed status, revealing the charis or "divine grace" that is thought to buoy and propel the charismatic mission.

Colossal players need not only be opponents. Rather, they can also simply be "players" whose company serves in its own right as a signal of the remarkable aspirations of the incipient charismatic leader. Barbara Finlay's (2002) tracing of the charismatic ascent of the twelfth-century nun Hildegard of Bingen $(1098-1179)$ is instructive on this point. Hildegard's power was augmented 
through her status as a public interlocutor with increasingly powerful figures, beginning with her confessor, then her bishop, and then her archbishop. The apex of her power saw her corresponding with and even admonishing Pope Eugenius III (d. 1153), and the display of these interactions-which would have been remarkable to onlookers considering the near complete exclusion of women from the power hierarchies of medieval Europe-allowed her to expand her own authority within an increasingly wide constituency (Finlay 2002, 548, 552 ).

The opening salvo of a charismatic career-what gets the aspiring charismatic leader noticed in the first place-will thus often be an audacious engagement with a colossal player, in the form of "plucky" expressions by someone whose confidence is larger than their present station. ${ }^{2}$ Thus, whereas the previous section described how certain competitive charismatic interactions can work to enshroud conventional rivals in an aura of "unworthiness," colossal players are by contrast utterly "worthy" because they are sparring partners who are capable of testing the mettle that should befit anyone claiming "superhuman, or exceptional powers or qualities" (Weber [1922] 1978, 241). Furthermore, because colossal players represent opportunities to engage in interactions that are "to scale" ${ }^{3}$ with the grandiose, revolutionary "missions" that typify charismatic aspiration (Weber [1922] 1978, 241, 439, 1115-117), the incipient charismatic leader will likely seek them out while brushing aside challenges from conventional opponents, furthering the interactional eclipse of unworthy challengers.

Throughout his career, Trump has displayed an awareness of how "thinking big" is a performative pose that is well suited for generating enthusiasm about himself and his projects. In The Art of the Deal, for example, he wrote:

$[\mathrm{K}]$ ey to the way I promote is bravado. I play to people's fantasies. People may not always think big themselves, but they can still get very excited by those who do. That's why a little hyperbole never hurts. People want to believe that something is the biggest and the greatest and the most spectacular. I call it truthful hyperbole. It's an innocent form of exaggeration - and a very effective form of promotion. (Trump and Schwartz 1987, 40)

A buoyant self-confidence thus seems to have been present within Trump not as a result of his early successes in the 2015-2016 campaign, but rather as a precondition to them. Indeed, at his campaign announcement speech in June 2015, when no mainstream commentators were taking him seriously, he proclaimed simply: "I will be the greatest jobs president God ever created" (Trump 2015).

Trump's expressions of extreme confidence have been manifold, ${ }^{4}$ and while it is obvious how this disposition may be inspiring to already-devoted followers, ${ }^{5}$ less immediately recognizable is how such hubris can invoke the performative bearing of colossal players who, in turn, offer their own distinct form of legitimation to the charismatic leader. Trump's work on Twitter has consistently displayed his penchant for engaging directly with world leaders, and at various points throughout the 2015 and 2016 campaign, he has received congratulations or (more often) condemnation from Angela Merkel, David Cameron, President Obama, and 
Vicente Fox. In January 2016, long before he had secured the nomination, the British Parliament was debating whether to ban him from entry to the UK to open his Scottish golf course. That same month, Al-Shabaab used him for propaganda purposes in one of their recruitment videos. In February 2016, none other than the Pope commented on Trump, questioning his faith. Needless to say, no other GOP candidate was amassing such an impressive array of citations. In order to see how these colossal players can provide grist for the mill of charismatic accession, however, we need to turn to the details of a few examples.

The first example came during the first question of the first GOP debate when, in contrast to the nine other candidates on stage, Trump raised his hand, signaling his refusal to pledge his support to the eventual Republican nominee, should it not be him. This impertinent act secured Trump's dominance of the headlines, ${ }^{6}$ but more importantly, it set the parameters for a narrative that would continue throughout the GOP primary contests; namely, that the real battle was not between Trump and the other aspiring nominees, but instead between Trump and a colossus: the GOP establishment itself. In the months to come, Trump would charismatically deliver in this midst of this contest-in Weberian ([1922] 1978, 266) parlance, he was able to maintain recognition via " "proof' before their eyes" (incredibly, to nearly all observers) with his frontrunner status, even as GOP establishment figures were endorsing other candidates and actively working against him.

The dynamics through which colossal players can be used to sideline and delegitimize unworthy challengers were also evident in Trump's interactions with Russian leader Vladimir Putin. Throughout the campaign, Trump frequently attacked GOP opponents by invoking Putin in the theater of the mind:

Marco Rubio, who stood with me [at a debate], he was with me when he had the meltdown, and I'm telling you it wasn't a pretty sight [laughter]...he was soaking wet, I'm telling you. He was wet, boy I said, "What the hell is going on over here?" I thought he just came out of a swimming pool, he was soaking. I said "Wow, [are] you OK?" Now when we get in with Putin, we need people that don't sweat, let me tell you [loud cheering]. Gotta have people who don't sweat. Can you imagine Putin sitting there waiting for the meeting and this guy walks in and he's like a wreck? Nah. [raising his voice] You gotta have Trump walk into that meeting folks! [loud cheering] We're gonna do very nicely [emphasis in the original] (February 15, 2016, South Carolina rally)

Two months prior to this, Putin had given an interview in which he referred to Trump as "talented" and "colorful" (Reevell 2015). At the February 13 debate in South Carolina, Trump claimed that Putin had "called me a genius" (an inaccuracy that was subsequently attributed to a mistranslation of Putin's Russian). Trump, in turn, reciprocated compliments toward the Russian leader at the GOP debate on March 10, 2016:

As far as Putin is concerned, I think Putin has been a very strong leader for Russia. I think he has been a lot stronger than our leader, that I can 
tell you. I mean, for Russia-that doesn't mean I'm endorsing Putin.... And strong doesn't mean good. Putin is a strong leader, absolutely. I could name many strong leaders. I could name very many very weak leaders. But he is a strong leader. Now I don't say that in a good way or a bad way. I say it as a fact.

In the charismatic-performative logic being advanced by Trump, the theme of Putin's "strength" is key for establishing his suitability as a "match" for Trump, who was at this point only an aspirant for power on the world stage. In the October 2015 debate in Colorado, Trump claimed to have established a certain mutuality with Putin, saying, "I got to know him very well because we were both on 60 Minutes. We were stablemates, and we did very well that night." Corrections soon followed when it was revealed that while Trump and Putin did appear on the same episode, their segments had been taped at different times and in different places and that they had not actually met (much less gotten to know each other "very well”). Trump's keenness to establish his mutuality with Putin-even, again, to the point of stretching the facts-is telling of his performative instincts. In the portrayal of himself and Putin as "stablemates," Trump was suggesting that they belonged in some sense in the same field of play.

Predictably, the response on the part of fellow GOP contenders to such posturing was one of outrage-outrage at the simple fact that Trump would express anything other than antipathy for the Russian leader. Similar moral objections attended Trump's former associations with the Republicans' most despised foe, Democratic nominee Hillary Clinton. As with the example of Putin, however, Trump was recalcitrant in the face of such objections. At the August 6, 2015, debate, a moderator asked Trump why conservatives should vote for someone who had previously given money to Clinton. Trump replied:

I will tell you that our system is broken. I gave to many people before this, before two months ago [when he had entered the race]. I was a businessman. I gave to everybody. When they call, I give. And do you know what? When I need something from them two years later, three years later, I call them [and] they are there for me.... With Hillary Clinton, I said "Be at my wedding" and she came to my wedding. She didn't have a choice because I gave.

Such brash defiance from Trump was similarly on exhibit later in the night when Fox News contributor Chris Wallace asked Trump about the casino developers who had lost money in their dealings with Trump in Atlantic City. Trump replied:

Let me just tell you about the lenders. First of all, these lenders aren't babies. These are total killers. These are not the nice, sweet little people that you think, OK? [laughter and applause]. You know, I mean, you're living in a world of the make-believe, Chris, [if] you want to know the truth [applause].... And let me just tell you. I had the good sense, and 
I've gotten a lot of credit in the financial pages, seven years ago I left Atlantic City before it totally cratered, and I made a lot of money in Atlantic City, and I'm very proud of it. I want to tell you that. Very proud of it. And by the way, this country right now owes $\$ 19$ trillion. And they need somebody like me to straighten out that mess [applause].

One might think that moral objections would be salient when considering Trump's association with the likes of Putin, Clinton, and the "killers" casino business. But the ineffectuality of such attacks exemplifies the notion that, as Weber famously stressed, charisma is not rooted in either traditional morality, or in any rational sense propriety when it comes to conducting one's affairs. He frequently references the likes of the "berserker warrior," the "charismatic pirate," and the "rank swindler" as exemplars because, among other things, charisma often manifests as a striking display of raw power ([1922] 1978, 242). The moral agnosticism of charismatic interaction led Weber to repeatedly stress that we must approach charisma in a "value-free" sense ([1922] 1978, 242, 1112-13, 1117), and this can account for why moral challenges to charismatic leaders can resemble a game of shadow-boxing, in which blows, even if well aimed, often fail to do damage to charismatic legitimacy (Joosse 2012, 190,195).

What mattered above all else in the case of Trump was that his associations with other "players" set him apart- "apart" from the unworthy challengers against which he was formally competing, but also "apart" in the more general Weberian/charismatic sense described in the introduction. In Orrin Klapp's (1962) terms, Trump serves as a contemporary example of the "winner": "heroes who beat everybody, get what they want, and come out on top." The GOP establishment, Putin, Clinton, and the "killers" of the casino business were crucial to his pitch to voters, because they allowed him to demonstrate "wins" in a manner that lent credibility to his promise of future Herculean feats as president.

\section{Conclusion}

One distinguishing feature of charisma is that it constitutes a "baffling success" within the societies where it emerges (Gerth and Mills [1946] 1958, 52). The political commentary from last year certainly evinced this bafflement with respect to Trump's success, describing him alternately as "Teflon Don" (Illing 2016); as someone who was able to "defy the modern laws of political gravity" (Luntz 2016); and as someone who consistently performed outrageously, in a manner that "would have ended the career of any ordinary politician" (Robinson 2015). For Trump, as with other charismatic leaders, such miracles were at once the substance and proof of his charismatic legitimacy (Weber [1946] 1958, 52).

Aside from this political commentary, the history of scholarship on charisma also indicates a significant measure of bafflement among Weber's academic heirs about how charisma "works" at the performative level. Past scholars have variously criticized Weber for producing a "mysterious" (Bourdieu [1971] 1987, 
129), "metaphysical" (Bensman and Givant 1975, 584), "irrational pseudo concept" (Lukács [1962] 1980, 631)—something that (in the theoretical extension of Shils) seems to issue from the "transcendental realm" (Downton 1973, 210). I submit that this tendency to be suspicious about the explanatory power of "charisma" is in part due to the fact that few scholars have directed their empirical examinations toward accounting for how interactions outside devotional relationships contribute to charismatic affect, and that this has resulted in trajectories of charismatic success within society that are apparently inexplicable, and consequently mysterious. While it is understandable that scholarly analyses, taking Weber's descriptions at face value, would start from the premise that charisma is something that exists primarily "inside the cult," or within the radical enthusiasm of the political sect, or in the feverish affect of a fan's devotion, the aim here has been to challenge this notion by describing how a variety of nondevotional actors-in this case, unworthy challengers and colossal players-also contribute to an interactional ecology that favors the proliferation of charismatic sentiments. To do this, it was necessary to read Weber's descriptions while harboring a fastidious commitment to relational sociology (Emirbayer 1997). From this vantage point, one can see how these additional charismatic counter-roles can become accomplices (if unwitting ones) to the modern miracle worker, and, moreover, how they are crucial performative mechanisms through which charisma periodically spills over and troubles the wider social order.

The present analysis suggests several directions for future research. First, more work would be needed to determine whether the three-fold taxonomy of counter-roles provided here is complete, or whether continued examinations of this case or others will suggest extensions. It may be, for example, that a fourth type-the incredulous onlooker-plays a key part in the act of charismatic proof itself, in that certain actors can work to define and calibrate popular expectations about the (seeming) impossibility of the feats that the charismatic leader performs. For example, the media's initial consensus that Trump was an unserious candidate, utterly incapable of any modicum of success, certainly set the stage for Trump to eventually "prove himself." It is difficult now to remember the days when GOP strategist Karl Rove was telling Fox News that Trump "is not a serious candidate", counseling viewers to simply "ignore him...he's completely off base" (Elkin 2015). It now seems quaint that, from July to December 2015, the Huffington Post filed all of its coverage of Trump in its Entertainment section, refusing, in their founder's words, "to go along with the idea, based simply on poll numbers, that Trump's candidacy was actually a serious and good faith effort to present ideas on how best to govern the country" (Huffington 2015). Those who took such a stance may have contributed to the amplification of amazement that occurred in the subsequent months when Trump experienced his first successes. As with the other counter-roles presented above, the category of the incredulous onlooker would imply a reversal of Weber's leader-centric descriptions of charisma, shifting focus from the leader's "proofs" ([1922] 1978, 242-44, 266, 441) to those who define what constitutes an amazing feat to begin with. Because the current dataset centered on Trump's own statements and not those of commentators, I was not able to collect enough 
evidence to substantiate the presence of this additional counter-role, even if the Weberian theory predicts it.

Second, this analysis may point the way toward elaborating theories of routinization. Weber devoted a lengthy section in Economy and Society to describing various routinizing processes ([1922] 1978, 1121-48), but because the counter-roles described here remained only implicit within his descriptions, Weber never examined how they may affect charisma's ossification, whether into traditional or rational-legal forms. Future analyses of the "post-charismatic moment"-in the case of Trump or otherwise-may seek to account for how those inhabiting various counter-roles adjust amid the institutionalization of charismatic power. In the wake of Trump's victory, for example, there has been much talk about "refusing to normalize" his speech and action (e.g., Sullivan 2016). The present analysis suggests, however, that Trump's charismatic appeal was able to grow as a result of his extraordinary performative interventions within and in opposition to the normal, routine protocols for journalistic coverage and political contestation. This raises the question of whether unworthy challengers and colossal players will grow wise to the ways in which they have contributed to his success and develop performative countermeasures themselves, or whether they will continue to recapitulate the patterns of interaction that augmented his authority during the campaign.

Third, while this research has explored the efficacy of counter-roles within politics, Weber regarded charisma as being constitutive of authority within the fields of religion, celebrity culture, military operation, and social movements more generally (Baehr 2008, 11-114; Eisenstadt 1968; Shils 1965; Willner and Willner 1965). Since charismatic processes are clearly salient for this wide range of fields, future work should seek to examine how various counter-roles are shaped by domain-specific structures, and, conversely, the extent to which they generalize to the universe of charismatic phenomena. Moreover, and more generally, as Eisenstadt's (1968) was able to show 50 years ago, charismatic interaction is not something that only flares up episodically, in moments of cultural disruption. Rather, it is a central feature of more general and gradual processes of sociocultural evolution and institution-building. Abrutyn and others have been instrumental in outlining the macro-level dimensions of such evolutionary processes (Abrutyn 2009; Abrutyn and Van Ness 2015; Eisenstadt 1964). It is my hope that the counter-roles I have outlined may be taken "inside" more mundane institutional settings and contribute to refinements and elaborations within new institutionalism.

\section{Notes}

1. Weber describes the leader as being "considered" extraordinary, "treated" as endowed with extraordinary powers that are "regarded" as being divine [Weber [1922] 1978, 241]), without offering much discussion of those who do the "considering," "treating," and "regarding."

2. Kohut asserts that charismatic leaders must "display an apparently unshakable selfconfidence and voice their opinions with absolute certainty" (1978, 825). 
3. On the concept of "scale," see Weber's discussion of "the feudal knight who measures swords with an equal adversary in order to gain personal honor" ([1922] 1978, 1149).

4. Trump has presented himself as peerless on an extraordinarily diverse range of issues. A selection: “There's nobody bigger or better at the military than I am" (quoted in Wilstein 2015); "nobody reads the Bible more than me" (Woolf 2016); and "nobody has more respect for women than Donald Trump!" (Trump 2016).

5. One supporter told the New York Times, "He doesn't just want to be president. He wants to be the greatest president... That works in our favor because he doesn't want to fail. He sees himself as too big to fail" (quoted in Parker and Haberman 2016).

6. A selection of headlines the day after the first GOP debate: "Trump at Center of GOP Tussle; Only Debater who won't commit to backing nominee” (Boston Globe); "It's All About Trump at Raucous Republican Debate" (Reuters); "Republican Debate: Trump Refuses to Rule Out Running for White House Alone" (The Times [UK]); "Mogul Sets a Raucous Tone in Showdown of 10 Republicans" (Washington Post); "Donald Trump Jolts First Republican Debate, Rivals Scramble for Attention" (Postmedia News); "On Cleveland stage, Trump trumps the field" (Philadelphia Daily News); "Trump Proves to be Boss in GOP Race" (Toronto Star).

7. In his Super Bowl interview, which aired February 5, 2017, Trump also called Putin a "killer," adding, "what, do you think our country is so innocent?"

\section{About the Author}

Paul Joosse is an assistant professor in the Department of Sociology at the University of Hong Kong. His past work on Weber, religion, and political sociology can be found in Sociological Theory, Journal of Classical Sociology, Sociology of Religion, and British Journal of Criminology, among others. He is currently researching the democracy movement in Hong Kong. Email: pjoosse@ hku.hk

\section{References}

Abel, Theodore. 1937. "The Pattern of a Successful Political Movement." American Sociological Review 2(3):347-52.

Abrutyn, Seth. 2009. "Toward a General Theory of Institutional Autonomy." Sociological Theory 27(4): 449-65.

Abrutyn, Seth, and Justin Van Ness. 2015. "The Role of Agency in Sociocultural Evolution: Institutional Entrepreneurship as a Force of Structural and Cultural Change." Thesis Eleven 127(1):52-77.

Adams, T. Becket. 2015. "Trump Attacks 'Liar' Reporter for Noting Small Crowd at Rally." Washington Examiner, September 24.

Alexander, Jeffrey. 2010. The Performance of Politics. Oxford and New York: Oxford University Press.

Althusser, Louis. 1967. "Contradiction and Over-Determination." New Left Review 41.

Baehr, Peter. 2008. Caesarism, Charisma, and Fate. New Brunswick and London: Transaction.

Bendix, Reinhard. 1960. Max Weber: An Intellectual Portrait. New York: Doubleday.

Benford, Robert, and David Snow. 2000. "Framing Processes and Social Movements: An Overview and Assessment." Annual Review of Sociology 26:611-39. 
Bennett, W. Lance. 2012. "The Personalization of Politics: Political Identity, Social Media, and Changing Patterns of Participation." The ANNALS of the American Academy of Political and Social Science 644 (1):20-39.

Bensman, Joseph, and Michael Givant. 1975. "Charisma and Modernity: The Use and Abuse of a Concept." Social Research 42:570-614.

Binder, Sarah. 2014. "How Political Polarization Creates Stalemates and Undermines Lawmaking." Washington Post, January 13.

Blasi, Anthony J. 1991. Making Charisma: The Social Construction of Paul's Public Image. New Brunswick and London: Transaction.

Bourdieu, Pierre. [1971] 1987. "Legitimation and Structured Interests in Weber's Sociology of Religion." In Max Weber, Rationality, and Modernity, edited by S. Lash and S. Whimster, 119-36. London and New York: Routledge.

Brants, Kees, and Peter Neijens. 1998. "The Infotainment of Politics." Political Communication 15(2): $149-64$.

Butler, Judith. 1990. Gender Trouble. New York and London: Routledge.

Campbell, Colin. 2015. “'Liar!': Donald Trump Attacks the New York Times for Besmirching His 'Massive' Crowd Size." Business Insider. September 24. http://www.businessinsider.com/donald-trump-nytcrowd-size.

Chan, Cheris Shun-Ching. 2013. "Doing Ideology Amid a Crisis: Collective Actions and Discourses of the Chinese Falun Gong Movement." Social Psychology Quarterly 76(1):1-24.

CNN. 2016. At This Hour with Berman and Bolduan. March 24.

Collins, Randall. 2004. Interaction Ritual Chains. Princeton, NJ: Princeton University Press.

Confessore, Nicholas, and Karen Yourish. 2016. "\$2 Billion Worth of Media for Donald Trump." New York Times, March 15.

Cooper, Anderson. 2015. "Interview with Donald Trump." Anderson Cooper 360, July 8.

Couch, Carl J. 1989. "From Hell to Utopia and Back to Hell: Charismatic Relationships." Symbolic Interaction 12(2):265-80.

Dawson, Lorne L. 2006. "Psychopathologies and the Attribution of Charisma: A Critical Introduction to the Psychology of Charisma and the Explanation of Violence in New Religious Movements." Nova Religio 10(2):3-28.

della Porta, Donatella. 1995. Social Movements, Political Violence and the State. Cambridge: Cambridge University Press.

Derman, Joshua. 2012. Max Weber in Politics and Social Thought: From Charisma to Canonization. Cambridge: Cambridge University Press.

Dickerson, John. 2015. Interview with Stephen Colbert, December 27.

Downton, J. V. 1973. Rebel Leadership. New York: Free Press.

DuPertuis, Lucy. 1986. "How People Recognize Charisma." Sociological Analysis 47(2):111-24.

Eilperin, Juliet, and Gref Jaffe. 2015. “White House Says Trump's Anti-Muslim Policy 'Disqualifies' Him from Serving as President." Washington Post, December 8.

Eisenstadt, Shmuel N. 1968. "Introduction." In On Charisma and Institution Building: Max Weber and Modern Sociology, edited by S. M. Eisenstadt, xi-Ivi. Chicago: University of Chicago Press.

Emirbayer, Mustafa. 1997. "Manifesto for a Relational Sociology." American Journal of Sociology 103(2): 281-317.

Finlay, Barbara. 2002. "The Origins of Charisma as Process: A Case Study of Hildegard Bingen." Symbolic Interaction 25(4):537-54.

Friedland, William. 1964. "For a Sociological Concept of Charisma." Social Forces 43(1):18-26.

Gamson, William. 1992. Talking Politics. New York: Cambridge University Press. 
Gardner, William, and Bruce Avolio. 1998. "The Charismatic Relationship: A Dramaturgical Perspective." Academy of Management Review 23(1):32-58.

Gass, Nick. 2015. “Donald Trump's Polling Obsession." Politico, October 12.

Geertz, Clifford. 1977. "Centers, Kings, and Charisma: Reflections on the Symbolics of Power." In Culture and Its Creators: Essays in honor of Edward Shils, 150-71. Chicago: University of Chicago Press.

Gerth, Hans. 1940. "The Nazi Party: Its Leadership and Composition." American Journal of Sociology 45:517-41.

Gerth, Hans, and C. Wright Mills. [1946] 1958. "Introduction." In Max Weber, From Max Weber, edited and introduced by H. H. Gerth and C. Wright Mills, 3-76. New York: Oxford University Press.

Girard, René. [1965] 2009. "Deceit, Desire, and the Novel." In The Novel: An Anthology of Criticism and Theory 1900-2000, edited by Dorothy J. Hale 294-314. Oxford: John Wiley \& Sons.

Goffman, Erving. 1959. The Presentation of Self in Everyday Life. Garden City, NY: Doubleday and Anchor Books.

- 1961. Encounters. Indianapolis: Bobbs-Merrill.

Green, Jeffrey Edward. 2010. The Eyes of the People: Democracy in an Age of Spectatorship. Oxford: Oxford University Press.

Grossman, Seth. 2015. "Donald Trump, Our Reality TV Candidate." New York Times, September 25.

Hochschild, Arlie. 2016. "The Ecstatic Edge of Politics: Sociology and Donald Trump." Contemporary Sociology 45(6):683-89.

Hofmann, David C. 2016. "The Influence of Charismatic Authority on Operational Strategies and Attack Outcomes of Terrorist Groups." Journal of Strategic Security 9:14-46.

Illing, Sean. 2016. "Teflon Don: Rubio and Cruz's Stampede of Attacks Won't Stop the Trump Juggernaut —Nothing Will Stick to This Guy." Salon, February 29.

Jameson, Frederic. 1973. "The Vanishing Mediator: Narrative Structure in Max Weber." New German Critique 1:52-89.

Joosse, Paul. 2012. "The Presentation of the Charismatic Self in Everyday Life: Reflections on a Canadian New Religious Movement." Sociology of Religion 73(2):174-99.

2014. "Becoming a God: Max Weber and the Social Construction of Charisma." Journal of Classical Sociology 14(3):266-83.

2017a. "Max Weber's Disciples: Theorizing the Charismatic Aristocracy." Sociological Theory 35(4):334-58.

2017b. "Expanding Moral Panic Theory to Include the Agency of Charismatic Entrepreneurs."

British Journal of Criminology. Advanced access: https://doi.org/10.1093/bjc/azx047.

Junker, Andrew. 2014. "Follower Agency and Charismatic Mobilization in Falun Gong." Sociology of

Religion 75(3):418-41.

Klapp, Orrin E. 1948. “The Creation of Popular Heroes." American Journal of Sociology 54(2):135-41.

1949. "The Fool as a Social Type." American Journal of Sociology 55(2):157-62.

1962. Heroes, Villains, and Fools: The Changing American Character. New York, NY: Prentice

Hall.

[1964] 2009. Symbolic Leaders: Public Dramas and Public Men. New Brunswick and London: Transaction.

Kohut, Heinz. 1976. The Search for the Self. Edited by P. Ornstein. New York: International Universities Press.

Kurzman, Charles. 1996. "Structural Opportunity and Perceived Opportunity in Social-Movement Theory: The Iranian Revolution of 1979." American Sociological Review 61:153-70.

Kushin, Matthew James, and Masahiro Yamamoto. 2010.“Did Social Media Really Matter? College Students' Use of Online Media and Political Decision Making in the 2008 Election." Mass Communication and Society 13(5):608-30. 
Limbaugh, Rush. 2016. "Trump Refuses to Play by the Rules." The Rush Limbaugh Show, January 27.

Lindholm, Charles. 1990. Charisma. Cambridge and Oxford: Basil Blackwell.

Lukács, Georg. 1962. The Destruction of Reason, trans. 1980. London: Merlin Press.

Luntz, Frank. 2016. "Donald Trump and Bernie Sanders Are Breaking All the Rules of Politics." The Telegraph, February 1.

MacDonald, Heather. 2016. “Trump's 'Riot' Comments Disqualify Him from the Presidency." National Review, March 18.

Meyer, David. 2016. "Trumpism and the Threat of Violence." Politics Outdoors. https://politicsoutdoors. com/2016/03/24/trumpism-and-the-threat-of-violence.

Moy, Patricia, Michael A. Xenos, and Verena K. Hess. 2005. "Communication and Citizenship: Mapping the Political Effects of Infotainment." Mass Communication \& Society 8(2):111-31.

Oakes, Len. 1997. Prophetic Charisma: The Psychology of Revolutionary Religious Personalities. Syracuse, NY: Syracuse University Press.

Oberschall, Anthony R. 1994. "Rational Choice in Collective Protests." Rationality and Society 6(1): 79-100.

Parker, Ashley, and Maggie Haberman. 2016. “Donald Trump's Backers Express Deep and Diverse Support." New YorkTimes, March 1. Available at: https:/www.nytimes.com/2016/03/02/us/politics/ donald-trump.html.

Ragin, Charles. 1994. Constructing Social Research: The Unity and Diversity of Method. Thousand Oaks, CA: Pine Forge Press.

Reed, Isaac Ariail. 2013. "Charismatic Performance: A Study of Bacon's Rebellion." American Journal of Cultural Sociology 1(2):254-87.

Reevell, Patrick. 2015. "Russian President Vladimir Putin Praises Donald Trump as 'Talented' and 'Very Colorful.'” ABC News, December 17.

Rose, Charlie. 2016. Interview with Louis CK, April 25.

Schiffer, Irvine. 1973. Charisma: A Psychoanalytic Look at Mass Society. Toronto: University of Toronto Press.

Schleifer, Theodore, and Noah Gray. 2015. “30,000 Turn Out for Trump's Alabama Pep Rally.” CNN, August 22.

Searle, John R. 1969. Speech Acts: An Essay in the Philosophy of Language, vol. 626. Cambridge: Cambridge University Press.

Shils, Edward. 1965. "Charisma, Order, Status." American Sociological Review 30:199-213.

Shirky, Clay. 2011. "The Political Power of Social Media." Foreign Affairs 90(1):28-41.

Smith, David N. 1998. "Faith, Reason, and Charisma: Rudolf Sohm, Max Weber, and the Theology of Grace." Sociological Inquiry 68(1):32-60.

—. 2013. "Charisma Disenchanted: Max Weber and His Critics." Current Perspectives in Social Theory 31:3-74.

Sullivan, Margaret. 2016. "A Call to Action for Journalists Covering Trump." Washington Post, November 9.

Tait, Robert. 2016. “Donald Trump's Refusal to Release Tax Returns 'Disqualifies' Him as President, Mitt Romney Says." The Telegraph, May 12.

Tarrow, Sidney. 1998. Power in Movement: Social Movements and Contentious Politics. Cambridge and New York: Cambridge University Press.

Thussu, Daya Kishan. 2008. News as Entertainment: The Rise of Global Infotainment. Thousand Oaks, CA: Sage.

Timmermans, Stefan, and Iddo Tavory. 2012. "Theory Construction in Qualitative Research: From Grounded Theory to Abductive Analysis." Sociological Theory 30(3):167-86.

Trump, Donald, and Tony Schwartz. 1987. Trump: The Art of the Deal. New York: Random House. 
Trump, Donald. 2015. Campaign Announcement Speech. June 16. 2016. Tweet from @realDonaldTrump, March 26.

Velencia, Janie. 2016. "This Donald Trump Rally Looks Like a Scene from Nazi Germany." Huffington Post, March 5.

Wagner-Pacifici, Robin, and Iddo Tavory. 2017. "Politics as a Vacation." American Journal of Cultural Sociology 5(3):307-321.

Wallis, Roy. 1982. "The Social Construction of Charisma." Social Compass 29(1):25-39.

Wasielewski, Patricia. 1985. "The Emotional Basis of Charisma." Symbolic Interaction 8(2):207-22.

Weber, Max. [1922] 1978. Economy and Society. 2 vols. edited by Guenther Roth and Claus Wittich. Berkeley, London, and Los Angeles: University of California Press.

—. [1919] 1946. From Max Weber, edited and introduced by H. H. Gerth and C. Wright Mills. New York: Oxford University Press.

- 1968. On Charisma and Institution Building: Max Weber and Modern Sociology. Chicago: University of Chicago Press.

Wehner, Peter. 2015. "Seeking President, No Experience Necessary." New York Times, October 3.

Wignall, Ross. 2016. "'A Man after God's Own Heart': Charisma, Masculinity and Leadership at a Charismatic Church in Brighton and Hove, UK." Religion 46:389-411.

Willner, Ann, and Dorothy Willner. 1965. "The Rise and Role of Charismatic Leaders." Annals of the American Academy of Political and Social Science 362(2):77-88.

Wilson, Bryan. 1975. The Noble Savages: The Primitive Origins of Charisma and Its Contemporary Survival. Berkeley: University of California Press.

Wilstein, Matt. 2015. "Trump Slams Jeb, Praises Putin in Extensive Interview with Bill O'Reilly." Mediaite. June 16. Available at: https://www.mediaite.com/tv/trump-slams-jeb-praises-putin-inextensive-interview-with-bill-oreilly/.

Woolf, Nicky. 2016. "The First Godless US Election." The New Statesman, May 31. Available at: https:// www.newstatesman.com/politics/religion/2016/05/first-godless-us-election.

Zald, Mayer, and Bert Useem. 1987. "Movement and Countermovement Interaction: Mobilization, Tactics, and State Involvement." In Social Movements in an Organizational Society, edited by Zald and McCarthy, 247-271. New Brunswick, NJ: Transaction Publishers.

Zhe, Ji. 2008. "Expectation, Affection and Responsibility: The Charismatic Journey of a New Buddhist Group in Taiwan." Nova Religio 12(2):48-68. 